\title{
Bone mineral density gains related to basketball practice in boys: cohort study
}

Mário Antônio Rodrigues Júnior², Ricardo Ribeiro Agostinete², Rafael Luiz de Marco², Igor Hideki Ito², Marcelo Rodrigues Ribeiro dos Santos ${ }^{2}$, Rômulo Araújo Fernandes ${ }^{1,2}$

DOI: http://dx.doi.org/10.7322/jhgd.127655

\begin{abstract}
Introduction: In recent decades, the prevalence of osteoporosis has significantly increased, impacting in a significant manner on health care costs worldwide.

Objective: To analyze the impact of basketball practice on bone mineral density of male adolescents.

Methods: 9 - month cohort study carried out with 27 adolescents (controls, $n=13$ [11.9 \pm 2.2 years] and basketball players, $n=14$ [13.4 \pm 1.2 years]). Bone mineral density was measured in different body segments (upper limbs, lower limbs, spine, and total) using the dual energy X-ray absorptiometry technique. Intake of vitamin D, chronological age, somatic maturation, fat-free mass, and height were adopted as confounders. The statistical analysis was composed of the Student's t-test, analysis of covariance, and Pearson/partial correlations.
\end{abstract}

Results: Regardless of confounders, there was a positive relationship between higher basketball practice time and bone density gains in the upper limbs $(r=0487[95 \% \mathrm{Cl}=0.131$ to 0.732$])$.

Conclusion: The practice of basketball seems to affect bone mineral density gains in adolescents, mainly when the practice is prolonged.

Keywords: bone density, adolescent medicine, sports medicine, basketball.

\section{INTRODUCTION}

In recent decades, the prevalence of osteoporosis has significantly increased, impacting in a significant manner on health care costs worldwide. It is estimated that in 2000 , about one percent of all retirement-related non-communicable diseases were attributed to osteoporotic fractures $^{1}$. In adolescence, the occurrence of bone fractures is a common event ${ }^{2,3}$, however due to trauma, not osteoporosis. In fact, there are cases of osteoporosis in childhood and adolescence, but the condition is very unusual ${ }^{4}$.

About $70 \%$ of bone phenotype variance is determined by genetic variants ${ }^{4}$, while the remainder of the variation is explained by factors such as nutrition, physical exercise, and others ${ }^{2}$. In the case of physical exercise, recommendations for improvement in bone health in childhood and adolescence are based on exercises that generate mechanical overload on the bone and are carried out at moderate/vigorous intensity 5 .
Accordingly, different sports include these characteristics, such as basketball. Basketball is a collective dynamic sports activity, which includes significant mechanical impact on bones (running, jumping, quick changes of direction, etc.) and is performed predominantly at moderate and vigorous intensity (intermittent feature) ${ }^{6}$.

Moreover, although widely practiced throughout the world, there is a shortage of scientific studies identifying the possible beneficial impact on bone growth and development in children and adolescents. The majority of these studies focus on international populations and sports such as soccer, tennis, swimming, and gymnastics ${ }^{7-10}$ and therefore very little is known about the adaptations that occur in the skeletons of young people exposed to basketball practice.

In this sense, the objective of this study was to analyze the impact of basketball practice on bone mineral density (BMD) in male adolescents.

1 Post-Graduate Program in Physical Therapy, São Paulo State University - UNESP, Presidente Prudente, Brazil.

2 Laboratory of Investigation in Exercise - LIVE, Department of Physical Education. Sao Paulo State University - UNESP, Presidente Prudente, Brazil.

Correspondig author: Mario Antonio Rodrigues Junior - e-mail: mario_edf@outlook.com

Suggested citation: Rodrigues Júnior MA, Agostinete RR, Luiz-de-Marco R, Ito IH, Ribeiro-dos-Santos MR, Fernandes RA. Bone mineral density gains related to basketball practice in boys: cohort study. J Hum Growth Dev. 2017; 27(1): 71-76. DOI: http://dx.doi. org/10.7322/jhgd.127655

Manuscript submitted: 12 May 2016, accepted for publication 16 Jun 2016. 


\section{METHODS}

\section{Sample}

This is a longitudinal study, which forms part of the cohort study entitled "The practice of different sports and bone mass gain: 9-month cohort", which was conducted from October 2013 to August 2014 in the city of Presidente Prudente. This study was approved by the ethics committee of the institution (Process: 216939/2013).

The sample size calculation was performed using an equation based on the comparison of two means (Student $\mathrm{t}$ test). Taking into account a minimum difference in BMD (whole body) of $0.10 \mathrm{~g} / \mathrm{cm}^{2}$ between the control and sports groups ${ }^{11}$, standard deviation of 0.14 $\mathrm{g} / \mathrm{cm}^{2}$ for the sports group and $0.10 \mathrm{~g} / \mathrm{cm}^{2}$ for controls, and an $80 \%$ power and $5 \%$ alpha $(Z=1.96)$. Thus, the estimated minimum sample size was 11 adolescents per group. The inclusion criteria adopted were as follows: (i) chronological age between 11 and 17 years, (ii) prior parental permission to participate in the study, (iii) prior authorization of coaches to participate in the study, (iv) a minimum of six months practice in the sport mode (basketball group) or the absence of any organized sports activities in the previous three months (control group), (v) not using medications that could affect bone metabolism and (vi) the consent form signed by a responsible adult.

The control group comprised 13 adolescent students enrolled in either public (school units held by nonprofit organizations were also considered) or private city schools. The basketball group was composed of 14 adolescents belonging to the basic team of the municipality, the state-level competitors, thus, the final sample included 27 individuals.

\section{Body Composition and bone variables}

The BMD $\left(\mathrm{g} / \mathrm{cm}^{2}\right)$, bone mineral content (BMC, grams $[\mathrm{g}]$ ), fat-free mass ([FFM] $\mathrm{kg}$ ), and trunk fat (TF [\%]) were assessed through dual energy X-ray absorptiometry (DXA-Lunar DPX-NT, General Electric Healthcare, Little Chalfont, Buckinghamshire, UK) using Medical System GE Lunar software (version 4.7). The scanner quality was tested by a trained technician before each measurement day, following the manufacturer's recommendations. At both moments of analysis, measurements were taken by the same evaluator. Participants were instructed to wear light clothing and no shoes, and remain in the supine position on the machine (about 15 minutes). Bone mineral density was measured in the whole body, which enables verification of the values of the upper and lower limbs and spine.

\section{Anthropometry and peak height velocity}

Body weight was measured using a digital scale (Filizola model Personal Line 200, Filizola Ltda., Brazil), with an accuracy of $0.1 \mathrm{~kg}$, and the height and sitting height were determined using a wooden stadiometer fixed on the wall (Sanny, Professional model, Sanny ${ }^{\circledR}$, Brazil) with an accuracy of $0.1 \mathrm{~cm}$, according to the procedures described in the literature ${ }^{12}$. Biological maturation was estimated by the peak height velocity (PHV), from math- ematical models based on anthropometric measurements, described by Mirwald et al, 2002 ${ }^{13}$. These equations represent time (in years) lacking (negative values) or passed (positive values) from PHV, which is characterized as an important biological event in the human aging process. The PHV has a strong relationship with the release of important hormones during puberty ${ }^{14}$.

\section{Vitamin D Score}

Although there was no nutritional monitoring in this cohort, with the help of a nutritionist, a questionnaire was created with groups of foods rich in vitamin D. Using a Likert frequency scale, the adolescents reported how often they consumed these foods in the week prior to the evaluation. The total score generated (all the food) was considered as vitamin D intake. In the present study, the sum of the scores from both moments was used as the vitamin D intake measure.

\section{Statistical analysis}

Descriptive statistics consisted of mean, standard deviation (SD), and 95\% confidence interval (95\% CI). Analysis of covariance (ANCOVA) compared changes in $\mathrm{BMD}$ in adolescents engaged and not engaged in the practice of basketball. In all ANCOVA models, homogeneity of variance was evaluated by the Levene's test, while the effect size measures were provided by Eta Squared (Small effect size: 0.010 , average effect size: 0.060 and large effect size: 0.140). Partial correlation examined the relationship between changes in BMD, the volume of weekly training, and previous time engagement in sport (adjusted for age, height, FFM, PHV, and vitamin D score). Statistical significance ( $p$-value) was set at $p<0.05$ and statistical software BioEstat (version 5.0) was used to perform analyzes.

\section{Results}

The total sample consisted of a group of 27 teenage males, who were followed for a period of nine months (Table 1). At baseline, the adolescents engaged in basketball practice were older $(p$-value $=0.047)$, heavier $(p$-value $=$ $0.001)$, taller $(\mathrm{p}=0.001)$, closer to achieving the PHV ( $p$ value $=0.018)$, and presented a greater amount of muscle mass $(\mathrm{p}=0.001)$. The trunk fat and vitamin D score did not differ between the groups, however, all BMD indicators were higher for the group engaged in sports ( $p$-value $=0.001$ for all).

Both groups analyzed presented significant gains in BMD in all body segments analyzed. In addition, although similar at baseline for both groups, the score of consumption of vitamin D differed between young people engaged and not engaged in basketball practice in the follow-up (Basketball $5.5 \pm 1.5$ and Control $4.1 \pm 1.7 ; p=0.026$ ).

Throughout the cohort, indicators of percentage change in BMD were similar between the adolescents engaged and not engaged in basketball practice in the region of the lower limbs $(p$-value $=0.642)$ and spine $(p$-value $=$ $0.748)$. On the other hand, in the region of the upper limbs $(p$-value $=0.001)$ and total body $(p$-value $=0.008)$ there were significant increases in BMD in the group of adolescents engaged in basketball practice. 
Table 1: General characteristics of adolescents engaged and not engaged in basketball practice $(n=27)$.

\begin{tabular}{|c|c|c|c|}
\hline Beginning of study & $\begin{array}{c}\text { Control }(n=13) \\
\text { Mean (SD) }\end{array}$ & $\begin{array}{c}\text { Basketball }(n=14) \\
\text { Mean }(S D)\end{array}$ & $p$ - value \\
\hline Age (years) & $11,9(2,2)$ & $13,4(1,2)$ & 0,047 \\
\hline Body mass $(\mathrm{kg})$ & $44,5(13,4)$ & $63,2(13,2)$ & 0,001 \\
\hline Heigth $(\mathrm{cm})$ & $154,5(13,1)$ & $175,3(7,4)$ & 0,001 \\
\hline PVC (years) & $-2,3(1,5)$ & $-1,1(0,9)$ & 0,018 \\
\hline FFM $(\mathrm{kg})$ & $33,2(8,7)$ & $48,3(7,4)$ & 0,001 \\
\hline TF $(\%)$ & $20,7(11,1)$ & $19,7(8,6)$ & 0,793 \\
\hline Vitamin D score & $5,6(1,4)$ & $5,3(1,4)$ & 0,566 \\
\hline \multicolumn{4}{|l|}{ DEXA - BMD $\left(\mathbf{g} / \mathrm{cm}^{2}\right)$} \\
\hline Upper limbs & $0,679(0,083)$ & $0,789(0,061)$ & 0,001 \\
\hline Lower limbs & $1,080(0,157)$ & $1,352(0,126)$ & 0,001 \\
\hline Spine & $0,857(0,130)$ & $1,078(0,164)$ & 0,001 \\
\hline Total & $1,001(0,101)$ & $1,163(0,091)$ & 0,001 \\
\hline Change (\%) & Média (IC95\%) & Média (IC95\%) & \\
\hline BMD - Upper limbs & $7,2(3,8$ a 10,6$)$ & $17,6(12,9$ a 22,2$)$ & 0,001 \\
\hline BMD - Lower limbs & $6,1(4,1$ a 8,1$)$ & $5,3(2,4$ a 8,2$)$ & 0,642 \\
\hline BMD - Spine & $4,9(2,5$ a 7,3$)$ & $5,6(2,1$ a 9,1$)$ & 0,748 \\
\hline BMD - Total & $4,1(2,8$ a 5,1$)$ & $7,1(5,1$ a 9,1$)$ & 0,008 \\
\hline
\end{tabular}

DEXA = dual energy $x$-ray absorptiometry; $B M D$ = bone mineral density; TF = trunk fat; FFM = fat free mass; PVC = peak growth rate; $\mathrm{SD}=$ standard deviation; $\mathrm{Cl} 195 \%=95 \%$ confidence interval.

In the follow-up, the percentage changes in BMD in different body segments were compared with regard to potential confounders (Table 2). As regards the region of the upper limbs, although the changes in BMD did not present statistical significance, the changes in the basketball practice group presented a moderate effect size (ES$\mathrm{r}=0.083)$. In the same model, the adjustment variables were not significant and presented low/trivial effect sizes.

Table 2: Alterations in the bone density indicators in adolescents engaged and not engaged in basketball practice $(n=27)$

\begin{tabular}{|c|c|c|c|c|c|c|c|}
\hline \multirow[b]{2}{*}{ DEXA BMD } & \multirow[b]{2}{*}{ Mean (IC95\%) } & \multicolumn{6}{|c|}{ ANCOVA Parameters (effect size measures [Eta-Squared]) DEXA-DMO } \\
\hline & & Basktball & Age & Height & PGV & FFM & Vitamin D \\
\hline $\begin{array}{l}\text { Upper limbs } \\
\text { Control }(n=13) \\
\text { Basketball }(n=14)\end{array}$ & $\begin{array}{c}9.4(3.7 \text { to } 15.1) \\
15.5(10.1 \text { to } 21.1)\end{array}$ & 0.083 & 0.001 & 0.011 & 0.016 & 0.029 & 0.031 \\
\hline $\begin{array}{l}\text { Lower limbs } \\
\text { Control }(n=13) \\
\text { Basketball }(n=14)\end{array}$ & $\begin{array}{l}5.3(2.3 \text { to } 8.2) \\
6.1(3.3 \text { to } 8.8)\end{array}$ & 0.006 & 0.014 & $0.178^{*}$ & 0.011 & $0.292^{* *}$ & 0.072 \\
\hline $\begin{array}{l}\text { Spine } \\
\text { Control }(n=13) \\
\text { Basketball }(n=14)\end{array}$ & $\begin{array}{l}5.1(1.1 \text { to } 9.2) \\
5.4(1.5 \text { to } 9.3)\end{array}$ & 0.001 & 0.003 & 0.020 & 0.001 & 0.016 & 0.093 \\
\hline $\begin{array}{l}\text { Total } \\
\text { Control }(n=13) \\
\text { Basketball }(n=14)\end{array}$ & $\begin{array}{l}4.5(2.4 \text { to } 6.6) \\
6.6(4.6 \text { to } 8.5)\end{array}$ & 0.074 & 0.030 & 0.100 & 0.056 & 0.027 & 0.150 \\
\hline
\end{tabular}

The changes in the region of the lower limbs were not affected by the practice of basketball (ES-r $=0.006$ [trivial effect]), but height (ES-r $=0.178$ [large effect]), and FFM (ES-r $=0.292$ [large effect]) were the main determinants of changes in BMD in this region of the body. In the spine, sports activities did not affect changes in BMD and no adjustment variable stood out. Finally, playing basketball $(\mathrm{ES}-\mathrm{r}=0.074$ [moderate effect]), height $(\mathrm{ES}-\mathrm{r}=$ 0.100 [moderate effect]), and consumption of foods rich in vitamin $\mathrm{D}(\mathrm{ES}-\mathrm{r}=0.150$ [large effect]) were highlighted in the effect of changes in total BMD.

Based on the parameters provided by the test for homogeneity of variances, except for total BMD (Total; $\mathrm{p}=0.001$ ), all other multivariate models created were ad- equately fitted (upper limbs; $\mathrm{p}$-value $=0.111 /$ lower limbs; $\mathrm{p}$-value $=0.225 /$ spine; $p$-value $=0.482$ ).

Finally, we tested the linear relationship between changes in the bone indicators, with prior basketball practice and weekly training volume (Table 3 ). It was observed that even after the adjustments, there was a positive relationship between longer basketball practice and density gains in the upper limbs $(\mathrm{r}=0.578$ [95\% CI, $0.254-0.785]$ ), as well as between higher density gains in the arms and weekly training volume $(\mathrm{r}=0.442$ [95\% CI, $0.074-0.704])$. In the model in which the previous sports practice time and training volume were inserted simultaneously, only prior training practice remained significant $(\mathrm{r}=0.487$ [95\% CI, 0.131-0.732]). 
Table 3: Relationship between alterations in indicators of bone density, prior practice time and volume of training $(n=27)$

\begin{tabular}{|c|c|c|c|c|}
\hline \multirow[b]{2}{*}{ Beginning of study } & \multicolumn{3}{|c|}{ Partial correlation (change over the cohort [\%]) } & \multirow[b]{2}{*}{$\begin{array}{l}\text { BMD Total } \\
\mathrm{r}(\mathrm{Cl} \mid 95 \%)\end{array}$} \\
\hline & $\begin{array}{l}\text { BMD Upper limbs } \\
\text { r (C195\%) }\end{array}$ & $\begin{array}{l}\text { BMD Lower limbs } \\
\text { r (C195\%) }\end{array}$ & $\begin{array}{l}\text { BMD Spine } \\
\text { r (CI95\%) }\end{array}$ & \\
\hline \multicolumn{5}{|c|}{ Entered separately in the model } \\
\hline Practice time (years) & $0.578(0.254 \text { to } 0.785)^{*}$ & $0.049(-0.337 \text { to } 0.421)^{*}$ & $0.294(-0.097 \text { to } 0.606)^{*}$ & $0.261(-0.132 \text { to } 0.583)^{*}$ \\
\hline Training volume (min/wk) & $0.442(0.074 \text { to } 0.704)^{*}$ & $0.048(-0.338 \text { to } 0.420)^{*}$ & $0.172(-0.223 \text { to } 0.518)^{*}$ & $0.296(-0.095 \text { to } 0.608)^{*}$ \\
\hline \multicolumn{5}{|c|}{ Entered simultaneously in the model } \\
\hline Practice time (years) & $0.487(0.131$ to 0.732$) \S$ & $0.032(-0.352$ to 0.407$) \S$ & $0.250(-0.144$ to 0.575$) \S$ & $0.162(-0.232$ to 0.511$) \S$ \\
\hline Training volume (min/wk) & $0.280(-0.112$ to 0.597$) \S$ & $0.031(-0.353$ to 0.406$) \S$ & $0.061(-0.327$ to 0.431$) \S$ & $0.216(-0.179$ to 0.551$) \S$ \\
\hline
\end{tabular}

* * $\quad$ = correlation adjusted for age, height, fat-free mass, peak height velocity, and vitamin D score; $\S=$ correlation adjusted for age, height, fat free mass, peak height velocity, vitamin $\mathrm{D}$ score, and prior practice time (for training volume), or volume of training (for prior practice time); $D E X A=$ dual energy $x$-ray absorptiometry; $B M D=$ bone mineral density; $C 195 \%=$ $95 \%$ confidence interval.

\section{DISCUSSION}

In the present study, young basketball players presented higher BMD and FFM at baseline. These findings corroborate previous research, which showed that young people engaged in sports activities have greater muscle mass, bone mass, and height ${ }^{15-18}$. On the other hand these findings may reflect not only the physiological effects of basketball practice (bone deformities caused by vibrations from the impact with the ground during running and jumping, as well as the stimulation of muscle contraction) $)^{19}$, but also the effects of the existing selection process in the sport, i.e., basketball players have more chance of being selected if they are taller and stronger.

The gains in BMD in the basketball players were significantly higher compared to the control group. In fact, the practice of basketball adds different biomechanical and physiological components (moderate/vigorous intensity, jumping, running, quick changes of direction $)^{6,20}$, which are identified by the American College of Sports Medicine as osteogenic ${ }^{5}$. Interleukin- 6 is an inflammatory agent which affects the functioning of the GH-IGF-1 axis and also the stem cell differentiation process in osteoclasts and osteoblasts ${ }^{21}$. Moreover, basketball besides being conducted in intensities considered important to enable the anti-inflammatory mechanisms linked to exercise ${ }^{21,}$ also helps control body fat (major producer of interleukin-6 in the body) ${ }^{22}$. These physiological pathways offer, at least in part, to support the understanding of how basketball practice can positively affect bone formation, but need further investigation.

It is worth noting that the most osteogenic effect of basketball practice occurred in the upper limbs. In this regard, Tenforde and Fredericson ${ }^{23}$ identified that bone mineral density increases more effectively in places directly affected by mechanical stress. In this sense, handling the ball and the frequent use of the arms for protection during the game can be characterized as osteogenic stimuli, which are not observed in the control group and thus justify the differences. The same theory ${ }^{23}$ could be applied to explain the absence of differences in the lower limbs, since human gait is a behavior with osteogenic characteristics performed daily, regardless of involvement in sports.
Variables affected by biological maturation proved to be important in the analyzed outcome. Biological maturation greatly affected both the gain in bone mass and gain in height and muscle mass ${ }^{24}$. In this sense, the role of biological maturation (and therefore the variables affected by it) on the analyzed outcome is not surprising and confirms the importance of being controlled. It is worth noting an important finding of this study, which shows that the longer engaged in basketball practice (years), were the largest BMD gains. In terms of health promotion in pediatric populations, this information has an important weight as it confirms the need to encourage regular sports activities among young ${ }^{25.26}$, especially in a society where physical inactivity and obesity are public health problems among children and adolescents ${ }^{27.28}$. Similarly, the practice of sports can take leading role in the fight against physical inactivity and obesity actions because it is characterized as an important component of physical activity of children and adolescents worldwide.

Although this study is notable for the absence of similar experiments in Brazil, its main limitations need to be highlighted. First, the sample only included boys, and caution is therefore needed in the inference of such findings for girls. As a second limitation, the short follow-up period, which could produce greater differences between the groups analyzed over a longer time. A third point to note is the lack of supervision of training parameters (intensity of training), which could impact on hormone release. Finally, calcium intake of participants was not controlled.

In summary, it is concluded that basketball practice appears to significantly impact on increases in bone mineral density in teenagers, and the strong effect of variables related to growth and maturation in the process are highlighted. Finally, the prolonged practice of sport seems to lead to more consistent gains in bone structure.

\section{ACKNOWLEDGMENT}

The Support Foundation of São Paulo (FAPESP [Process 2013 / 06963-5 and Process 2015 / 13543-8]) to fund the study. 


\section{REFERENCES}

1. Johnell $\mathrm{O}$, Kanis JA. An estimate of the worldwide prevalence and disability associated with osteoporotic fractures. Osteoporos Int. 2006;17(12):1726-33. DOI: http://dx.doi.org/10.1007/s00198-006-0172-4

2. Landin LA. Epidemiology of children's fractures. J Pediatr Orthop B. 1997;6(2):79-83.

3. Khosla S, Melton LJ $3^{\text {rd }}$, Dekutoski MB, Achenbach SJ, Oberg AL, Riggs BL. Incidence of childhood distal forearm fractures over 30 years: a population $\square$ based study. JAMA. 2003;17;290(11):1479-85. DOI: http:// dx.doi.org/10.1001/jama.290.11.1479

4. Ma NS, Gordon MC. Pediatric Osteoporosis: Where are we now? J Pediatr. 2012; 161(6):983-90. DOI: http://dx.doi.org/10.1016/j.jpeds.2012.07.057

5. Kohrt WM, Bloomfield SA, Little KD, Nelson ME, Yingling VR; American College of Sports Medicine. American College of Sports Medicine Position Stand: physical activity and bone health. Med Sci Sports Exerc. 2004;36911):1985-96.

6. Narazaki K, Berg K, Stergiou N, Chen B. Physiological demands of competitive basketball. Scand J Med Sci Sports. 2009;19:425-432.

7. Zouch $M$, Jaffré $C$, Thomas $T$, Frère $D$, Courteix $D$, Vico $L$, et al. Long-term soccer practice increases bone mineral content gain in prepubescent boys. Joint Bone Spine. 2008;75(1):41-9. DOI: http://dx.doi. org/10.1016/j.jbspin.2006.12.008

8. Burt LA, Naughton GA, Greene DA, Courteix D, Ducher G. Non-elite gymnastics participation is associated with greater bone strength, muscle size, and function in pre- and early pubertal girls. Osteoporos Int. 2012;23:1277-86. DOI: http://dx.doi.org/10.1007/s00198-011-1677-z

9. Ducher G, Courteix D, Même S, Magni C, Viala JF, Benhamou CL. Bone geometry in response to longterm tennis playing and its relationship with muscle volume: A quantitative magnetic resonance imaging study in tennis players. Bone. 2005;37(4):457-66. DOI: http://dx.doi.org/10.1016/j.bone.2005.05.014

10. Gómez-Bruton A, Gónzalez-Agüero A, Gómez-Cabello A, Casajús JA, Vicente-Rodríguez G. Is bone tissue really affected by swimming? A systematic review. PLoS One. 2013;8(8):e70119. DOI: http://dx.doi. org/10.1371/journal.pone.0070119

11. Nebigh A, Rebai H, Elloumi M, Bahlous A, Zouch M, Zaouali M, et al. Bone mineral density of young boy soccer players at different pubertal stages: relationships with hormonal concentration. Joint Bone Spine. 2009;76(1):63-9. DOI: http://dx.doi.org/10.1016/j.jbspin.2008.03.002

12. Gordon CC, Chumlea WC, Roche AF. Stature, recumbent length, and weight. In: Lohman TG, Roche AF, Martorell R. Anthropometric standardization reference manual. Champaign: Human Kinetics Books. 1988; p.3-8.

13. Mirwald RL, Baxter-Jones AD, Bailey DA, Beunen GP. An assessment of maturity from anthropometric measurements. Med Sci Sports Exerc. 2002;34(4):689-94. DOI: http://dx.doi.org/10.1097/00005768200204000-00020

14. Cole TJ, Ahmed ML, Preece MA, Hindmarsh P, Dunger DB. The relationship between Insulin-like Growth Factor 1, sex steroids and timing of the pubertal growth spurt. Clin Endocrinol (Oxf). 2015;82(6):862-9. DOI: http://dx.doi.org/10.1111/cen.12682

15. Souza AM, Pereira RA, Yokoo EM, Levy RB, Sichieri R. Most consumed foods in Brazil: National Dietary Survey 2008-2009. Rev Saude Publica. 2013;47(Supl. 1):190S-99. DOI: http://dx.doi.org/10.1590/S003489102013000700005

16. Ferry B, Lespessailles E, Rochcongar P, Duclos M, Couteix D. Bone health during late adolescence: Effects of an 8-month training program on bone geometry in female athletes. Joint Bone Spine. 2013;80(1):57-63. DOI: http://dx.doi.org/10.1016/j.jbspin.2012.01.006

17. Dias Quiterio AL, Carnero EA, Baptista FM, Sardinha LB. Skeletal mass in adolescent male athletes and nonathletes: relationships with high-impact sports. J Strength Cond Res. 2011;25(12):3439-47. DOI: http:// dx.doi.org/10.1519/JSC.0b013e318216003b

18. Courteix D, Lespessailles E, Jaffre C, Obert P, Benhamou CL. Bone material acquisition and somatic development in highly trained girl gymnasts. Acta Paediatr. 1999;88(8):803-8.

19. Zouch M, Chaari H, Zribi A, Bouajina E, Vico L, Aleandre C, et al. Volleyball and Basketball Enhanced Bone Mass in Prepubescent Boys. J Clin Densitom. 2016; 19(3):396-403. DOI: http://dx.doi.org/10.1016/j. jocd.2015.07.001

20. Gonzalo-Skok O, Serna J, Rhea RM, Marín JP. Relationships between functional movement tests and performance tests in young elite male basketball players. Int J Sports Phys Ther. 2015;1095):628-38.

21. Nielsen RA, Pedersen BK. The Biological roles of exersice-induced cytokines: IL-6, IL-8, and IL-15. Appl Physiol Nutr Metab. 2007; 32(5):833-9. DOI: http://dx.doi.org/10.1139/H07-054

22. Cao JJ. Effects of obesity on bone metabolism. J Orthop Surg Res. 2011;6:30. DOI: http://dx.doi. org/10.1186/1749-799X-6-30

23. Tenforde AS, Fredericson M. Influence of sports participation on bone health in the young athlete: a review of the literature. PM R. 2011;3(9):861-7. DOI: http://dx.doi.org/10.1016/j.pmrj.2011.05.019

24. Kemper HC. Physical activity, physical fitness, and bone health. In: Armstrong N, Mechelen WV. Paediatric Exercise Science and Medicine. Oxford: Oxford; 2006; p. 365-74.

25. Fernandes RA, Zanesco A. Early physical activity promotes lower prevalence of chronic diseases in adulthood. Hypertens Res. 2010;33(9):926-31. DOI: http://dx.doi.org/10.1038/hr.2010.106

26. Lima MCS, Barbosa MF, Diniz TA, Codogno JS, Freitas Júnior IF, Fernandes RA. Early and current physi- 
cal activity: relationship with intima-media thickness and metabolic variables in adulthood. Braz $\mathrm{J}$ Phys Ther. 2014;18(5):462-9. DOI: http://dx.doi.org/10.1590/bjpt-rbf.2014.0040

27. Duncan S, Duncan EK, Fernandes RA, Buonani C, Bastos KD, Segatto AF, et al. Modifiable risk factors for overweight and obesity in children and adolescents from São Paulo, Brazil. BMC Public Health. 2011;11:585. DOI: http://dx.doi.org/10.1186/1471-2458-11-585

28. Fernandes RA, Reichert FF, Monteiro HL, Freitas Júnior IF, Cardoso JR, Ronque ER, et al. Characteristics of family nucleus as correlates of regular participation in sports among adolescents. Int $\mathrm{J}$ Public Health. 2012;57(2):431-5. DOI: http://dx.doi.org/10.1007/s00038-010-0207-7

This article is distributed under the terms of the Creative Commons Attribution 4.0 International License (http://creativecommons.org/licenses/by/4.0/), which permits unrestricted use, distribution, and reproduction in any medium, provided you give appropriate credit to the original author(s) and the source, provide a link to the Creative Commons license, and indicate if changes were made. The Creative Commons Public Domain Dedication waiver (http://creativecommons.org/publicdomain/zero/1.0/) applies to the data made available in this article, unless otherwise stated.

\section{Resumo}

Introdução: Ao longo das últimas décadas, a prevalência de osteoporose tem aumentado de forma significativa, impactando de maneira relevante nos custos com a saúde em todo o mundo.

Objetivo: Analisar o efeito da prática de basquetebol na densidade mineral óssea de adolescentes do sexo masculino.

Método: Coorte de 9 meses de seguimento realizado com 27 adolescentes $(n=13$ controles [11,9 \pm 2,2 anos] e $n=14$ jogadores [13,4 $\pm 1,2$ anos]). Densidade mineral óssea foi mensurada em diferentes regiões do corpo (membros superiores, membros inferiores, espinha e total) por meio da técnica de absortiometria de raio-x de dupla energia. Consumo de vitamina $D$, idade cronológica, maturação somática, massa livre de gordura e estatura foram adotados como fatores de confusão. Análise estatística foi composta pelo teste t de Student, análise de covariância e correlação de Pearson e parcial.

Resultados: Independentemente dos fatores de confusão, houve relação positiva entre maior tempo de prática do basquetebol e ganhos de densidade nos braços e corpo total ( $r=0.487$ [IC95\% $=0.131$ a $0.732] ; r=0.162$ [IC95\% = - 0.232 a 0.511]).

Conclusão: A prática do basquetebol parece impactar significativamente os ganhos de densidade mineral óssea de adolescentes.

Palavras-chave: densidade óssea, medicina do adolescente, medicina esportiva, basquetebol. 